\title{
Dotan Leshem, The Origins of Neoliberalism: Modeling the Economy from Jesus to Foucault (New York: Columbia University Press, 2016), ISBN: 9780231177764.
}

Although Dotam Leshem stakes out the ambitious project of exploring models of the economy from Jesus to Foucault, the true brilliance of his work lies about a fourth of the way between the two, amongst the early theologians of the Christian Church. In his recent book, Leshem puts forward a provocative thesis - that our concept of economic growth as the driving factor of human life derives not from the early modern period, as is commonly thought, but rather from changing concepts of Christian economy that took place between the Councils of Nicea in 325 CE and Chalcedon in 451 CE (1). Although others have characterized The Origins of Neoliberalism as a study in political theology, Leshem conceptualizes his work as "a philological history that traces the meanings attached to the notion of oikonomia since its original use as management and dispensation (nemein) of the oikos in Archaic Greek until today" (2). In other words, Leshem is telling a story, a story about how economics came to be the operating logic of human society, or in his words, how "the one-dimensional zoon oikonomikon came to reign supreme in the human trinity" of economy, politics, and philosophy. This story, however, has little to do with Jesus or Foucault. The scope of the work is enormous, moving in the course of 181 pages from Aristotle to Hannah Arendt, but its argumentative core lies with the Early Church Fathers, and specifically Gregory of Nyssa.

In terms of challenging our understanding of economic history, the key to Leshem's book is the transformation of oikonomia, or economy, from the classical to the Christian period. In classical Greek thought, argues Leshem, oikonomia is the prudent disposition of the excess of nature. Man, "by harnessing this excess" can generate a surplus that allows him to participate in political and philosophical life (15). In other words, one manages one's economic life in order to generate resources to subsidize the life of political action and contemplation. Of course, one can create such surplus in two ways, either by accumulating wealth, or, perhaps more nobly, by reducing one's needs in the style of Diogenes the Cynic. The important point is that these three dimensions--economy, politics, and philosophy--are thought of as separate spheres of human life. Moving into the Christian period, argues Leshem, "economists" such as Paul seek to include "all spheres of life in the economy instead of generating political and philosophical spheres that are "economicless'" (28). As such, the concept of "economy" in the Early Christian 
Church comes to describe many facets of Christian life, including the relationship between the parts of the Trinity, between the believer and Christ, within the community of believers, and the ultimate balancing of the scales at the end of time. As the master once managed the Greek household, God comes to manage human history. Economy is described by the $2^{\text {nd }}$ century theologian, Irenaeus, as "the history of the divine plan conducted in the bounds of the world that begins with creation, at its epicenter the incarnation of the Son of God in the Son of Adam and culminates with recapitulation at the fullness of the ages" (37). Thus, the first intervention Leshem makes in the philology of "economy" is to show that the economic sphere subsumes both the political and philosophical realms in early Christian thought. However, that is only one part of his story. Gregory of Nyssa provides the rest.

To be brief, Gregory of Nyssa, writing in the $4^{\text {th }}$ century, gives us the concept of the perpetual growth economy. According to Leshem, Gregory, like other Christian thinkers of his time, believes that humans have a choice between two economies, the economy of the human sphere, which is essentially "an economy of vice in which man enslaves himself to the circularity of excessive bodily desires" (93), and the economy of God, which relies on an "open-ended hermeneutical circle" based on "the human condition of becoming" (92). Ultimately, states Leshem, "Gregory was the first in the history of Greek philosophy ${ }^{1}$ to freely think and enable an economy in which humans can desire without limits and was also the first who, instead of being preoccupied with setting a boundary to the economy, simply set economy's boundary beyond the reach of human consciousness" (94). In other words, when one desires material goods or bodily pleasures, one eventually becomes sated. One cannot desire such things without limits. However, when one desires God, one can desire him with infinite desire. "This is because God, as a limitless object of desire, generates unsaturated desire in that the gap between man, as a created being, and God as infinite" (94). Moreover, in the human economy, one is trapped in a pointless circle-desire-saturation-desire. However, in the economy of God, one does not circle pointlessly, but rather spirals toward the divine, in a "never-ending journey into darkness," the darkness of "the true presence of God" (91-92). This, then, is the central move in Leshem's argument that the foundation of our current understanding of "economy" has its roots in the $4^{\text {th }}$ century, specifically in the philosophical genius of Gregory of Nyssa, who takes the concept of human life as ruled by God's economy and argues that humans can be in a perpetual state of becoming through their limitless desire for God. Leshem notes, "[e]ventually, Gregory concluded that the insatiable desire for the divine object becomes itself the object of desire, and growth for its own sake becomes the ultimate test and goal of the economy generated by the society of believers" (164). In the end, "economic stability [is] achieved by unlimited economic growth" (96).

Clearly this argument strikes at the heart of attempts to understand the totalizing of the economy as a radical break between modernity and pre-modernity, and in this way,

1 Of course Leshem is not suggesting that Gregory was a Greek philosopher, but that he was operating in the tradition of Greek philosophy represented by classical understandings of self-cultivation through contemplation of the divine, i.e. Plato's theory of the soul as a mirror for Go(o)d. 
it is supremely Foucauldian. Like Foucault in the History of Sexuality, Leshem urges us to see the continuities in understandings of the economy rather than its ruptures. Instead of viewing a religious logic as opposed to an economic one, Leshem argues that our economic way of understanding the world is in fact Christian. Of course Foucault also believes that many of our modern political, philosophical, and economic approaches are sanitized Christianity. What is the incessant need to talk about our sexuality, if not a desire to confess our transvalued sins? Another way in which Leshem's book partakes of Foucault's tool kit is its genealogical approach. Leshem is clear that he is departing from the typical method in the history of economics by treating "economy" as a concept that transforms over time, rather than as a transcendental sphere of human existence or a human disposition or form of conduct based on a specific type of rationality. Moreover, his method is Foucauldian in the sense that he demonstrates that changing discourses do in fact change the world materially, both by orienting individuals to reality in certain ways and thus conducting their conduct, and also through the tangible structures that emerge from ideas. We might say, for instance, that the invisible hand of the market is not the delineation of a universal law, but rather a phantasm brought to life and sustained through our belief in it. Thus, while Leshem's book does not strongly contribute to our understanding of Foucault's late work, ${ }^{2}$ it does serve as an excellent model of Foucauldian practice.

That said, a pervasive and problematic theme that occurs in The Origins of Neoliberalism is the tendency to schematize. For instance, Chapter 4 contains "[a] short history of the first three hundred years of patristic exegesis of Philippians 3:20-21, Matthew 22:21, Romans 13:1-7, and 1 Timothy 2:1-2, as well as the way these verses interplay in homilies" (11). Indeed, several parts of the text attempt to cover broad swathes of history in a few pages. Similarly, complex ideas are frequently discussed in extremely concise ways, as for example with the two paragraphs devoted to the coexistence of cosmological and anthropological economies in Christianity (53). These moments certainly speak to Leshem's erudition, which is truly impressive, but can be daunting for a reader unfamiliar with the basic material of his study, particularly the theology of the Church fathers. Finally, the book seeks not only to trace the transformation of the concept of economy from the classical period through early Christianity, a project which is itself highly demanding, but also to intervene in philosophical discussions of these issues in the work of Michel Foucault, Giorgio Agamben, and Hannah Arendt. As a result of this massive scope, the book often feels breathless, and the reader would be grateful for a slightly less intense pace. Truly, this monograph could have been broken into several projects--one outlining the central argument concerning the transformation of the idea of economy in early Christianity, another drawing parallels to the modern neoliberal economy, and perhaps a series of articles surrounding the interventions Leshem wants to make with

2 Leshem's Foucauldian intervention is fairly modest, focusing on "bring[ing] Foucault's work to completion" (6) by filling some holes in his narrative concerning pastoral power and neoliberal governmentality. 
Agamben, Foucault, and Arendt. Expanding the work in this way would have given Leshem's analysis room to truly shine.

Ultimately, this is a profound thesis buried in a dense book. It would be more appealing and valuable to a scholar interested in political theology or the economy in early Christian thought than those hoping for a deep engagement with Foucault's thought on pastoral power, care of the self, or neoliberal governmentality. This is also not the book for economists or lay readers interested in the origins of our modern perpetual-growth economy. Although the final chapter makes a strong case for the importance of Leshem's work as a first step toward critiquing neoliberalism and thus rebalancing the human trinity of economics, politics, and philosophy, many readers will find themselves in over their heads in the vast sea of Christian theology. The danger of erudition is inaccessibility, and this book demonstrates a surplus of both.

Author info

Tara Dankel

Harvard University

USA 